\title{
The effect of dietary vitamin $E$ and fatty acid supplementation of pregnant and lactating ewes on placental and mammary transfer of vitamin $\mathbf{E}$ to the lamb
}

\author{
Judith L. Capper $^{1 *}$, Robert G. Wilkinson ${ }^{1}$, Eleni Kasapidou ${ }^{2}$, Sandra E. Pattinson ${ }^{1}$, Alexander M. Mackenzie ${ }^{1}$ \\ and Liam A. Sinclair ${ }^{1}$ \\ ${ }^{1}$ Harper Adams University College, Edgmond, Newport, Shropshire TF10 8NB, UK \\ ${ }^{2}$ Division of Food Animal Science, University of Bristol, Langford, Bristol BS40 5DU, UK
}

(Received 9 September 2004 - Revised 17 November 2004 - Accepted 18 November 2004)

\begin{abstract}
The present study investigated the effect of maternal vitamin $\mathrm{E}$ and fatty acid supplementation on lamb antioxidant status. Forty-eight ewes were fed one of four concentrate diets supplemented with a basal $(50 \mathrm{mg} / \mathrm{kg}$ ) or supranutritional $(500 \mathrm{mg} / \mathrm{kg})$ level of vitamin E plus a source of either saturated fat (Mega$1 \mathrm{lac}{ }^{\circledR}$; Volac Ltd, Royston, Hertfordshire, UK) or long-chain PUFA (fish oil) from 6 weeks prepartum until 4 weeks postpartum. Blood samples were taken from ewes and lambs at intervals throughout the experiment and, at parturition, muscle, brain and blood samples were obtained from twelve lambs (three per treatment). Colostrum and milk samples were obtained at $12 \mathrm{~h}$ and $21 \mathrm{~d}$ after parturition, respectively. Supranutritional vitamin E supplementation of the ewe significantly increased concentrations of vitamin $\mathrm{E}$ in neonatal lamb tissues although plasma concentrations were undetectable. A significant increase in lamb birth weight resulted from increasing the dietary vitamin E supply to the ewe. Furthermore, maternal plasma, colostrum and milk vitamin E concentrations were increased by vitamin E supplementation, as were lamb plasma concentrations at $14 \mathrm{~d}$ of age. Neonatal vitamin E status was not significantly affected by fat source although plasma vitamin E concentrations in both ewes and suckling lambs were reduced by fish oil supplementation of the ewe. Fish oil supplementation reduced vitamin E concentrations in colostrum and milk and the activity of glutathione peroxidase in suckling lambs. The data suggest that the vitamin $\mathrm{E}$ status of the neonatal and suckling lamb may be manipulated by vitamin E supplementation of the ewe during pregnancy and lactation.
\end{abstract}

Birth weight: PUFA: Vitamin E: Colostrum

Four million lambs are estimated to die during the neonatal period on hill and upland farms each year in the UK, representing a substantial financial loss to the sheep industry (Merrell, 1998). A major factor contributing to this high mortality rate is hypothermia due to delayed suckling and exhaustion of brown fat reserves (Slee, 1981). Standing and suckling as soon as possible after birth is therefore imperative to facilitate the ingestion of colostrum and ensure maximal lamb survival (O'Connor \& Lawrence, 1992). Supplementing ewes with supranutritional dietary vitamin E during pregnancy has been reported to produce lambs that were more vigorous immediately after birth and had higher weight gains prior to weaning (Merrell, 1998), although the mechanism behind this response is unclear. It is well established that the vitamin $\mathrm{E}$ concentrations within plasma of neonatal mammals are low compared with maternal concentrations (Malone, 1975). Njeru et al. (1994) investigated the effects of maternal vitamin E supplementation upon the transfer of vitamin $\mathrm{E}$ to the neonatal lamb and concluded that placental transfer is inefficient in the sheep. Furthermore, Mahan \& Vallet (1997) reviewed vitamin transfer across the placenta in pigs and concluded that although a small amount of vitamin $\mathrm{E}$ is conveyed to the fetus, neonatal pigs are born deficient in vitamin $\mathrm{E}$ and therefore can obtain it in appreciable amounts only from the sow's colostrum. The low efficiency of placental transfer may be attributed to the large molecular size of the vitamin or to the low efficiency of lipid transfer with which vitamin $\mathrm{E}$ is associated (Njeru et al. 1994). By contrast, there appears to be no barrier to the transfer of vitamin $\mathrm{E}$ into colostrum and milk via the mammary gland (Njeru et al. 1994); indeed, fat-soluble vitamins are concentrated in colostrum (Hidiroglou et al. 2001). Consequently, it is postulated that, prior to the ingestion of colostrum, the vitamin $\mathrm{E}$ status of neonatal ruminants cannot be manipulated via the maternal diet (Njeru et al. 1994).

The long-chain PUFA docosahexaenoic acid and arachidonic acid have been implicated in the development of fetal brain and nervous tissue (Innis, 1991) and the addition of PUFA to the diet of human infants has been associated with improvements in infant vigour via enhanced neural and visual development (Carlson \& Werkman, 1996). Ruminant diets supply negligible amounts of these fatty acids (Givens et al. 2000), and it may therefore be argued that pregnant ruminants may be deficient in essential PUFA and benefit from supplementation. Furthermore, despite high levels of ruminal biohydrogenation of dietary PUFA (Wachira et al. 2000; Chikunya et al. 2004), feeding diets high in docosahexaenoic acid has been demonstrated to substantially increase concentrations of these fatty acids within polar and neutral lipids 
in sheep (Cooper et al. 2004; Demirel et al. 2004). Supplementation of pregnant ewes with PUFA may have positive effects in terms of lamb vigour (Capper et al. 2002); however, it may also increase the oxidative challenge to the animal, with concurrent effects upon the antioxidant status. A primary role of vitamin $\mathrm{E}$ is as a fat-soluble chain-breaking antioxidant essential for the prevention of lipid peroxidation in cell membranes (Wang \& Quinn, 1999), particularly during periods of rapid cell growth in the fetal and neonatal animal.

Apparent conflicting results have been reported regarding low maternofetal transfer of vitamin $\mathrm{E}$ and concurrent effects of maternal supplementation upon lamb vigour and performance. These results may further be complicated by fatty acid supplementation of the dam. Therefore, the objectives of the present experiment were to evaluate the effects of supplementing pregnant and lactating ewes with vitamin $\mathrm{E}$ and fatty acids upon the placental and mammary transfer of vitamin $\mathrm{E}$ to the fetal and suckling lamb.

\section{Materials and methods}

\section{Experimental design and treatments}

The present experiment was carried out at Harper Adams University College in accordance with the Animal (Scientific Procedures) Act 1986. Thirty-six twin-bearing and twelve triplet-bearing ewes were chosen from the Harper Adams early-lambing flock and used in a $2 \times 2$ factorial design. Pregnant ewes were scanned at $84 \mathrm{~d}$ of gestation and weighed and condition-scored at $90 \mathrm{~d}$ of gestation according to the method described by Russel et al. (1969), before being allocated to treatments according to breed, age, litter size, live weight and condition score. The ewe breeds used in the experiment were the Suffolk $\times$ North Country Mule ( $n$ 24), Charollais $\times$ Friesland $(n$ 20) and Friesland $\times$ Lleyn $(n$ 4). Ewes were impregnated by Charollais rams. The majority of the ewes ( $n$ 44) were multiparous with a mean age of 3.2 (SD 1.86) years, mean live weight of 76.6 (SD 6.14) $\mathrm{kg}$ and mean condition score of 3.32 (SD 0.51).

A basal diet was formulated, containing barley, sugarbeet pulp, soyabean meal, Sopralin ${ }^{\circledR}$ (a source of formaldehyde-protected soyabean meal; Trouw Nutrition UK, Northwich, Cheshire, UK), rapeseed meal, urea, molasses and a vitamin/mineral supplement $(30 \mathrm{~g} / \mathrm{kg})$ containing either a basal $(50 \mathrm{mg} / \mathrm{kg})$ or a supranutritional $(500 \mathrm{mg} / \mathrm{kg})$ concentration of vitamin E ( $\alpha$-tocopherol acetate; Roche UK Ltd, Heanor, Derbyshire, UK; Table 1). To this diet was added either a long-chain PUFA or control fat premix, each at $120 \mathrm{~g} / \mathrm{kg}$. The PUFA premix comprised a mixture of crude unrefined Scandinavian fish oil mixed at a ratio of 0.75:0.25 with Incromega ${ }^{\circledR}$ (Trouw Nutrition UK), a by-product of $n-3$ fatty acid production for the human market, high in docosahexaenoic acid. Cooper et al. (2002) demonstrated that vermiculite was effective in reducing the biohydrogenation of PUFA within the rumen, therefore both the fish oil and Incromega were combined with a vermiculite carrier (Trouw Nutrition UK). The control fat source consisted of a commercial protected fat source $\left(\right.$ Megalac ${ }^{\circledR}$; Volac Ltd, Royston, Hertfordshire, UK) mixed with straw pellets. The two premixes were formulated to provide equal concentrations of fatty acids $(60 \mathrm{~g} / \mathrm{kg}$ fresh weight) within the treatment concentrates. The treatment diets were therefore: MB, Megalac plus basal vitamin E; MS, Megalac plus supranutritional vitamin E; FB, fish oil plus basal vitamin E; and FS, fish oil plus supranutritional vitamin E. The treatment diets were formulated to be isoenergetic (11.4 MJ metabolisable energy/kg DM) and isonitrogenous (180 g
Table 1. Raw material and determined chemical composition of the treatment concentrates differing in vitamin $\mathrm{E}$ concentration and fatty acid source

\begin{tabular}{|c|c|c|c|c|}
\hline \multirow{2}{*}{$\begin{array}{l}\text { Fat source } \\
\text { Vitamin E level }\end{array}$} & \multicolumn{2}{|c|}{ Megalac } & \multicolumn{2}{|c|}{ Fish oil } \\
\hline & Low & High & Low & High \\
\hline \multicolumn{5}{|l|}{ Ingredients ( $\mathrm{g} / \mathrm{kg}$ fresh weight) } \\
\hline Barley & 457 & 457 & 523 & 523 \\
\hline Sugarbeet pulp & 100 & 100 & 100 & 100 \\
\hline Soyabean meal & 100 & 100 & 100 & 100 \\
\hline Rapeseed meal & 50 & 50 & 50 & 50 \\
\hline Sopralin ${ }^{\circledR *}$ & 8 & 8 & 12 & 12 \\
\hline Megalac ${ }^{\circledR} \dagger$ & 52 & 52 & - & - \\
\hline Straw & 68 & 68 & - & - \\
\hline Straw pellets & 70 & 70 & - & - \\
\hline Fish oil & - & - & 45 & 45 \\
\hline Incromega ${ }^{\circledR} \ddagger$ & - & - & 15 & 15 \\
\hline Vermiculite & - & - & 60 & 60 \\
\hline Molasses & 50 & 50 & 50 & 50 \\
\hline Urea & 15 & 15 & 15 & 15 \\
\hline Vitamins/minerals§ & 30 & 30 & 30 & 30 \\
\hline \multicolumn{5}{|c|}{ Chemical composition (g/kg DM) } \\
\hline $\mathrm{DM}(\mathrm{g} / \mathrm{kg})$ & 859 & 865 & 865 & 863 \\
\hline Organic matter & 923 & 931 & 895 & 884 \\
\hline Ash & 77 & 69 & 105 & 116 \\
\hline Crude protein $(\mathrm{N} \times 6.25)$ & 186 & 181 & 172 & 176 \\
\hline Neutral-detergent fibre & 199 & 223 & 128 & 145 \\
\hline Total fatty acids & 102 & 97 & 93 & 81 \\
\hline Total PUFA & 23.4 & $23 \cdot 2$ & $45 \cdot 5$ & $35 \cdot 4$ \\
\hline Total $n-3$ fatty acids & $1 \cdot 75$ & $1 \cdot 83$ & $11 \cdot 7$ & $7 \cdot 50$ \\
\hline Total $n-6$ fatty acids & $19 \cdot 5$ & $20 \cdot 3$ & $15 \cdot 6$ & $16 \cdot 2$ \\
\hline Vitamin E (mg/kg DM) & 57 & 503 & 64 & 541 \\
\hline
\end{tabular}

* Protected soyabean supplement (Trouw Nutrition UK, Northwich, Cheshire, UK). † Ca soap of palm fatty acid distillate (Volac Ltd, Royston, Hertfordshire, UK).

$\ddagger$ A by-product of $n-3$ fatty acid production for the human market, high in docosahexaenoic acid (Trouw Nutrition UK).

$\S$ Vitamin/mineral supplement (Roche UK Ltd, Heanor, Derbyshire, UK) supplied per kg diet: $\mathrm{Ca}, 7.06 \mathrm{~g}$; Na, $2.67 \mathrm{~g}$; P, $1.65 \mathrm{~g}$; Se, $0.36 \mathrm{mg}$; vitamin A, $4.32 \mathrm{mg}$; vitamin D, $0.75 \mathrm{mg}$; vitamin $\mathrm{E}, 50 \mathrm{mg}$ (basal) or $500 \mathrm{mg}$ (supranutritional).

crude protein $/ \mathrm{kg}$ DM) according to Agricultural and Food Research Council (1993) guidelines.

\section{Experimental procedure}

Ewes were housed and individually penned on sawdust from 6 weeks prepartum to 4 weeks postpartum. The concentrate ration was fed in two equal meals during pregnancy at 08.00 and 16.00 hours, stepped from $0.7 \mathrm{~kg} / \mathrm{d}$ at $103 \mathrm{~d}$ of gestation for twin-bearing ewes $(0.8 \mathrm{~kg} / \mathrm{d}$ for triplet-bearing ewes) to $1.2 \mathrm{~kg} / \mathrm{d}$ at $140 \mathrm{~d}$ of gestation $(1.3 \mathrm{~kg} / \mathrm{d}$ for triplet-bearing ewes), and was fed in three equal meals (at 08.00, 12.00 and 16.00 hours) at a flat rate of $1.7 \mathrm{~kg} / \mathrm{d}$ during lactation. Barley straw was offered ad libitum, fed at a rate of $125 \%$ of daily intake and calculated by weighing back refusals three times per week. Blood samples were obtained from ewes by jugular venepuncture into evacuated plasma tubes containing lithium heparin, potassium oxalate or no additive, at 11.00 hours on days 103,117 and 131 of gestation and at days 14 and 28 into lactation. Only plasma samples taken at days 103 and 131 of gestation and day 14 of lactation were analysed for vitamin E. At parturition, the second-born lamb from each triplet-bearing ewe was removed immediately after expulsion and the weight and sex recorded. Lambs were then killed by an intrajugular injection of sodium pentobarbitone $\left(200 \mathrm{mg} / \mathrm{ml}\right.$, Pentoject ${ }^{\circledR}$; AnimalCare Ltd, Dunnington, York, UK) at $0.8 \mathrm{ml} / \mathrm{kg}$ live weight. Immediately after cessation of the 
heartbeat was confirmed by stethoscope, blood samples were obtained by cardiac puncture and collected in evacuated tubes containing either lithium heparin or potassium oxalate. The brain was removed according to the procedure documented by the US Department of Agriculture Plant and Animal Health Inspection Service (2001) and the semimembranosis muscle dissected from the left hind leg. Tissue samples were stored at $-20^{\circ} \mathrm{C}$ before analysis. The weight and sex of all surviving lambs were recorded at $12 \mathrm{~h}$ postpartum.

Colostrum and milk samples were taken from ewes using a method adapted from Pattinson \& Thomas (2004). At $12 \mathrm{~h}$ postpartum, lambs were confined behind a wire mesh barrier within the pen, then $1 \mathrm{ml}$ oxytocin $\left(10 \mathrm{IU} / \mathrm{ml}\right.$, Oxytocin Leo ${ }^{\circledR}$; LEO Animal Health, Princes Risborough, Buckinghamshire, UK) was administered to the ewe by intramuscular injection, and the udder hand-milked until empty. At $16 \mathrm{~h}$ postpartum, $1 \mathrm{ml}$ oxytocin was administered by intramuscular injection, and the udder again hand-milked until empty. The total volume of colostrum produced was recorded and the colostrum secretion rate calculated for the interval between the end of the first and second milking. Subsamples were taken and stored at $-20^{\circ} \mathrm{C}$ before analysis. At $21 \mathrm{~d}$ postpartum, the procedure was repeated in order to measure milk yield and obtain samples for compositional analysis. Blood samples were taken by jugular venepuncture from 14-d-old lambs at 11.00 hours and collected into evacuated tubes containing lithium heparin, potassium oxalate or no additive.

\section{Chemical analyses}

Feed samples were bulked and analysed for DM and ash according to the method described by the Association of Official Analytical Chemists (1990). Crude protein was determined by the Kjeldahl method (Kjeltec 1035 analyser; Foss UK Ltd, Cheshire, UK) and neutral-detergent fibre by the method of Van Soest et al. (1991). Analysis of fatty acids within feed samples was executed by the method reported by Wachira et al. (2002) with samples being saponified in a solution of $5 \mathrm{M}-\mathrm{KOH}$ in aqueous methanol before extraction of fatty acids into petroleum spirit and methylation of individual fatty acids using diazomethane. Methyl esters of the fatty acids were then injected into a PerkinElmer 8500 gas chromatograph (PerkinElmer Life and Analytical Sciences Ltd, Boston, MA, USA) comprising a $50 \mathrm{~m} \times 0.22 \mathrm{~mm}$ internal diameter fused silica capillary column (model number 50QC2/BPX70 0.25; SGE International Pty Ltd, Ringwood, Victoria, Australia), a flame-ionisation detector and a PerkinElmer AS 8300 autosampler (SGE International Pty Ltd). He gas was employed as the carrier and total fatty acids were quantified with reference to an internal standard of 21:0 (Thames Restek UK Ltd, Windsor, Berkshire, UK). Individual peaks were identified by the retention times of a fatty acid methyl ester standard (Sigma-Aldrich, Poole, Dorset, UK) and the linearity of response confirmed using a reference mixture of fatty acid methyl esters (fatty acid methyl ester 5) containing equivalent amounts of $16: 1 n-9,18: 1 n-9$ cis, 20:1, 22:1 and 24:1 (Thames Restek UK Ltd).

Packed cell volume of whole blood was determined by the capillary microhaematocrit method (Hawksley and Sons Ltd, Lancing, West Sussex, UK). Plasma and serum were produced from blood samples by centrifugation at $2290 \mathrm{~g}$ for $5 \mathrm{~min}$ before storage at $-20^{\circ} \mathrm{C}$. Whole blood samples were analysed for glutathione peroxidase (GPx) using an RS504 kit (Randox,
Crumlin, Country Antrim, UK) and serum samples analysed for creatine kinase (CK) using a TO1-1882-85 kit (Bayer Diagnostics, Strawberry Hill, Newbury, Berkshire, UK). Both analyses were performed on a Technicon RA-1000 autoanalyser (Bayer Diagnostics).

Quantification of vitamin E within plasma, milk and tissue samples was performed by HPLC following solvent extraction. Vitamin $\mathrm{E}$ in plasma samples was determined by a modification of the method reported by McMurray \& Blanchflower (1979). Milk and colostrum vitamin $\mathrm{E}$ concentrations were determined according to a modification of the method of Burton et al. (1985) employing extraction in ethanol and hexane. Lipids within muscle samples were subjected to hydrolysis by a solution of $\mathrm{KOH}$ before extraction of vitamin $\mathrm{E}$ into hexane (Liu et al. 1996), while brain samples were subject to the same procedure with an added saponification stage. Reagent blanks (containing about $0.75 \mathrm{ml}$ distilled water to approximate the water content of the muscle samples) and standards of rac 5,7-dimethyltocol were used to quantify results and were prepared using the earlier-mentioned procedure. Elutant from colostrum, milk and tissue samples was passed through a normal phase column packed with silica $(250 \mathrm{~mm} \times 4.6 \mathrm{~mm}$ Techsphere with $5 \mu \mathrm{m}$ particle size; HPLC Technology, Macclesfield, Cheshire, UK) with a mobile phase of $96 \%$ n-hexane-methanol and $4 \%$ 1,4-dioxane within an isocratic HPLC apparatus (Gilson Inc., Middleton, WI, USA). The HPLC was calibrated using nine standard solutions containing known concentrations of $\alpha$-tocopherol ranging from 0.01 to $5 \mu \mathrm{g}$. Fluorescence detection of vitamin $\mathrm{E}$ was at an excitation of $297 \mathrm{~nm}$ and emission of $330 \mathrm{~nm}$. The concentration of $\alpha$-tocopherol in the sample was calculated according to analysis of the peak height for $\alpha$-tocopherol compared with internal and external standards. Reported concentrations of vitamin $\mathrm{E}$ were adjusted to account for percentage recoveries $(94 \%$ for colostrum, $93 \%$ for milk, $86 \%$ for muscle, $95 \%$ for brain). Feed samples were analysed for vitamin E by HPLC according to the method of Manz \& Philipp (1981), the analysis being performed by Roche UK Ltd.

\section{Statistical analyses}

All data were analysed as a factorial $2 \times 2$ completely randomised block design with fat source and dietary vitamin E concentration and their interaction as the main effects using a general ANOVA in the statistical package Genstat ${ }^{\circledR} 6.2$ (Lawes Agricultural Trust, Harpenden, Hertfordshire, UK, 2002).

\section{Results}

\section{Feed analysis}

The four treatment diets had a similar chemical composition with mean values for $\mathrm{DM}$, organic matter and crude protein $(\mathrm{N} \times 6.25)$ of $863 \mathrm{~g} / \mathrm{kg}, 908 \mathrm{~g} / \mathrm{kg}$ DM and $179 \mathrm{~g} / \mathrm{kg}$ DM, respectively. Concentrations of neutral-detergent fibre were lower, and the ash contents higher in the diets containing fish oil as a result of vermiculite inclusion, with mean values of 137 and $111 \mathrm{~g} / \mathrm{kg} \mathrm{DM}$ (fish oil) $v$. 211 and $73 \mathrm{~g} / \mathrm{kg}$ DM (Megalac) for neutral-detergent fibre and ash, respectively. Vitamin E concentrations were similar to those predicted by the diet formulation with means of 61 and $522 \mathrm{mg} / \mathrm{kg}$ DM for the basal and supranutritional diets, respectively. Total fatty acid concentrations were higher in diets supplemented with 


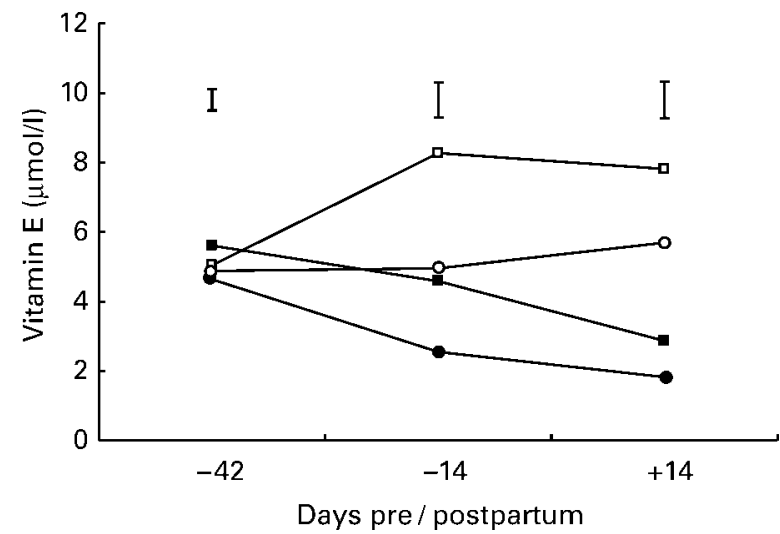

Fig. 1. Plasma vitamin $E$ concentrations in ewes fed diets containing Megalac ${ }^{\circledR}(\mathrm{M}$; Ca soap of palm fatty acid distillate, Volac Ltd, Royston, Hertfordshire, UK) or fish oil (F; Trouw UK Ltd, Northwich, Cheshire, UK) supplemented with either 50 (B) or 500 (S) $\mathrm{mg} \alpha$-tocopherol acetate/kg. $\mathbf{\square}$, MB; $\square$, MS; •, FB; O, FS. For details of diets and procedures, see Table 1 and p. 550. Values are means with standard errors shown by vertical bars (twelve ewes per group).

Megalac (100 g/kg DM) than in those containing fish oil $(87 \mathrm{~g} / \mathrm{kg}$ DM). Compared with diets based on Megalac, the addition of fish oil to treatment diets increased the dietary supply of polyunsaturated $(40.4 v .23 .3 \mathrm{~g} / \mathrm{kg} \mathrm{DM})$ and $n-3(9 \cdot 6 v .1 \cdot 8 \mathrm{~g} / \mathrm{kg} \mathrm{DM})$ fatty acids. Furthermore, the concentration of total $n-6$ fatty acids was reduced in the diets containing fish oil $(15.9 \mathrm{~g} / \mathrm{kg} \mathrm{DM})$, in contrast to the Megalac diets $(19.9 \mathrm{~g} / \mathrm{kg} \mathrm{DM})$.

\section{Ewe antioxidant status}

Plasma vitamin E concentrations were similar between treatments at $42 \mathrm{~d}$ prepartum (Fig. 1). The vitamin E concentration within plasma at $14 \mathrm{~d}$ prepartum was increased by supranutritional dietary supplementation of the ewe $(P<0 \cdot 001)$; in contrast, addition of PUFA to the diet reduced the concentration of vitamin E within plasma at $14 \mathrm{~d}$ prepartum $(P<0 \cdot 001)$. Supranutritional vitamin E supplementation increased plasma concentrations postpartum compared with basal supplementation $(P<0.001)$, while feeding diets containing fish oil reduced vitamin $\mathrm{E}$ concentrations compared with diets based on Megalac $(P<0.001)$.

The provision of treatment diets to pregnant ewes reduced the activity of GPx and the concentration of CK compared with pretreatment values (Table 2). When contrasted with ewes fed Megalac, supplementation of ewes with long-chain PUFA reduced mean prepartum GPx activity $(P<0.001)$. A similar pattern was seen during lactation $(P<0 \cdot 01)$. No main or interaction effects of dietary treatment were observed on ewe serum CK concentrations at any time point.

Colostrum yield was not significantly affected by dietary vitamin E supply; however, supplementation with long-chain PUFA reduced colostrum yield compared with feeding Megalac $(P<0.01)$ The vitamin $\mathrm{E}$ concentration of colostrum mirrored maternal prepartum plasma vitamin E concentrations, with the highest amounts being recorded in supranutritionally supplemented ewes $(P<0 \cdot 001)$. An interaction between dietary vitamin $\mathrm{E}$ concentration and fat source was also observed on colostrum vitamin E concentration $(P<0.001)$ and yield $(P<0.001)$, with higher amounts of vitamin $\mathrm{E}$ recorded in samples from ewes fed diet MS compared with ewes fed any of the other three treatment diets. Furthermore, adding long-chain PUFA to the diets reduced colostrum vitamin E concentration $(P<0 \cdot 001)$ and yield $(P<0 \cdot 001)$. Similar effects of dietary vitamin E concentration $(P<0.001)$, fat source $(P<0.01)$ and an interaction between the two $(P<0 \cdot 05)$ were observed for milk vitamin $\mathrm{E}$ concentration. Milk yield was not altered significantly by either dietary vitamin $\mathrm{E}$ supply or fat source. Milk vitamin $\mathrm{E}$ yield was increased by supranutritional vitamin $\mathrm{E}$ supplementation of the ewe $(P<0.01)$ although it was unaffected by dietary fat source.

Table 2. Effect of vitamin $E$ and fatty acid supplementation of ewes on parameters of antioxidant status in ewest‡

\begin{tabular}{|c|c|c|c|c|c|c|c|c|}
\hline & \multicolumn{4}{|c|}{ Diet§ } & \multirow[b]{2}{*}{ SED } & \multicolumn{3}{|c|}{ Significance } \\
\hline & MB & MS & FB & FS & & Fat source & Vitamin E & Interaction \\
\hline \multicolumn{9}{|l|}{ Pre-treatment (103d of gestation) } \\
\hline Mean erythrocyte GPx activity (U/mI PCV) & 191 & 173 & 161 & 186 & $24 \cdot 6$ & NS & NS & NS \\
\hline Mean CK activity (U/I) & 488 & 337 & 839 & 241 & $441 \cdot 1$ & NS & NS & NS \\
\hline \multicolumn{9}{|l|}{ Prepartum } \\
\hline Mean erythrocyte GPx activity (U/mI PCV) & 171 & 164 & 109 & 130 & $13 \cdot 8$ & $\star \star \star *$ & NS & NS \\
\hline Mean CK activity (U/I) & 259 & 209 & 393 & 179 & $143 \cdot 1$ & NS & NS & NS \\
\hline \multicolumn{9}{|l|}{ Postpartum } \\
\hline Mean erythrocyte GPx activity (U/ml PCV) & 185 & 185 & 160 & 147 & $14 \cdot 1$ & ** & NS & NS \\
\hline Mean CK activity $(\mathrm{U} / \mathrm{l})$ & 135 & 165 & 188 & 261 & $55 \cdot 0$ & NS & NS & NS \\
\hline Colostrum yield (ml/h) & 95 & 119 & 77 & 72 & $15 \cdot 2$ & ** & NS & NS \\
\hline Colostrum vitamin E concentration $(\mu \mathrm{g} / \mathrm{g})$ & $8 \cdot 23$ & $27 \cdot 40$ & 6.93 & $9 \cdot 26$ & 1.814 & 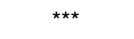 & 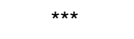 & $\star \star \star \star ~$ \\
\hline Colostrum vitamin E yield $(\mu \mathrm{g} / \mathrm{h})$ & 947 & 2846 & 908 & 1061 & $186 \cdot 5$ & *** & $\star \star * *$ & $* \star *$ \\
\hline Milk yield $(\mathrm{ml} / \mathrm{h})$ & 97 & 83 & 92 & 102 & $11 \cdot 1$ & NS & NS & NS \\
\hline Milk vitamin E concentration $(\mu \mathrm{g} / \mathrm{g})$ & 0.95 & 3.44 & 0.65 & 1.96 & 0.329 & $\star *$ & $* \star *$ & * \\
\hline
\end{tabular}

GPx, glutathione peroxidase; PCV, packed cell volume; CK, creatine kinase.

Mean prepartum activities $=$ mean of values measured at 14 and $28 \mathrm{~d}$ prepartum; mean postpartum activities $=$ mean of values measured at 14 and $28 \mathrm{~d}$ postpartum.

Significance level: ${ }^{*} P<0.05,{ }^{\star \star} P<0.01,{ }^{* \star \star} P<0.001$

$\dagger$ For details of diets and procedures, see Table 1 and p. 550

$\ddagger \mathrm{MB}, n 12$; MS, $n 11 ; \mathrm{FB}, n 11 ; \mathrm{FS}, n 12$.

$\S \mathrm{MB}$, Megalac ${ }^{\oplus}$ (Ca soap of palm fatty acid distillate; Volac Ltd, Royston, Hertfordshire, UK) plus $50 \mathrm{mg}$ vitamin E/kg; MS, Megalac plus $500 \mathrm{mg}$ vitamin E/kg; FB, fish oil plus $50 \mathrm{mg}$ vitamin $\mathrm{E} / \mathrm{kg}$; FS, fish oil plus $500 \mathrm{mg}$ vitamin $\mathrm{E} / \mathrm{kg}$. 
Table 3. Effect of vitamin $E$ and fatty acid supplementation of ewes on lamb birth weight and suckling lamb antioxidant status $\dagger$

\begin{tabular}{|c|c|c|c|c|c|c|c|c|}
\hline & \multicolumn{4}{|c|}{ Dietł } & \multirow[b]{2}{*}{ SED } & \multicolumn{3}{|c|}{ Significance } \\
\hline & MB & MS & $\mathrm{FB}$ & FS & & Fat source & Vitamin $\mathrm{E}$ & Interaction \\
\hline Lamb birth weight $(\mathrm{kg}) \S$ & 3.87 & $4 \cdot 01$ & 3.85 & $4 \cdot 33$ & 0.190 & NS & * & NS \\
\hline \multicolumn{9}{|l|}{ Suckling lambs ( $14 \mathrm{~d}$ of age)\| } \\
\hline Erythrocyte GPx (U/ml PCV) & 289 & 308 & 273 & 277 & $16 \cdot 3$ & * & NS & NS \\
\hline Serum CK (U/I) & 194 & 143 & 456 & 421 & $162 \cdot 7$ & * & NS & NS \\
\hline
\end{tabular}

GPx, glutathione peroxidase; PCV, packed cell volume; CK, creatine kinase.

Significance level: ${ }^{*} P<0.05$.

†For details of diets and procedures, see Table 1 and p. 550

$\ddagger$ MB, Megalac ${ }^{\circledast}$ (Ca soap of palm fatty acid distillate; Volac Ltd, Royston, Hertfordshire, UK) plus $50 \mathrm{mg}$ vitamin E/kg; MS, Megalac plus $500 \mathrm{mg}$ vitamin E/kg; FB, fish oil plus $50 \mathrm{mg}$ vitamin $\mathrm{E} / \mathrm{kg} ; \mathrm{FS}$, fish oil plus $500 \mathrm{mg}$ vitamin $\mathrm{E} / \mathrm{kg}$.

$\S \mathrm{MB}, n$ 23; MS, $n$ 23; FB, $n$ 24; FS, $n 24$.

$\| \mathrm{MB}, n$ 22; MS, $n$ 23; FB, $n$ 22; FS, $n 23$.

\section{Neonatal lamb birth weight and antioxidant status}

Lambs born to ewes fed supranutritional concentrations of vitamin $\mathrm{E}$ during pregnancy were heavier at birth $(P<0.05)$ by an average of $0.31 \mathrm{~kg}$ (Table 3 ). This parameter was not affected by maternal dietary fat source. Plasma vitamin E was undetectable in nine out of twelve neonatal plasma samples $(<0.1 \mu \mathrm{mol} / \mathrm{l})$, being measurable only in lambs from ewes fed diets MS (two samples) and FS (one sample). Vitamin E concentrations in brain tissue were elevated in lambs from treatments MS and FS compared with the basal treatment groups $(P<0.05)$, with there being no significant effect of maternal PUFA supplementation on vitamin E concentration (Fig. 2). The vitamin $\mathrm{E}$ concentration of neonatal semimembranosis muscle was also significantly augmented by maternal supranutritional supplementation $(P<0 \cdot 01)$. Lambs born to ewes fed diets supplemented with long-chain PUFA exhibited decreased muscle vitamin $\mathrm{E}$ concentrations, although these differences were not statistically significant $(P>0 \cdot 05$; Fig. 2$)$.

\section{Suckling lamb antioxidant status}

Fig. 3 shows the vitamin E concentrations within lamb plasma at $14 \mathrm{~d}$ of age. Main effects of maternal dietary vitamin E concentration $(P<0.001)$ and fat source $(P<0.001)$ were demonstrated,

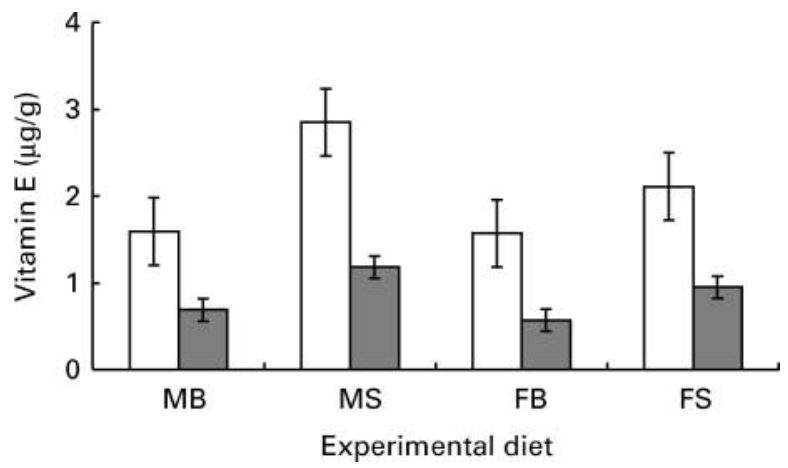

Fig. 2. Brain $(\square)$ and semimembranosis muscle ( $\square$ ) vitamin $E$ concentrations in lambs from ewes fed diets containing Megalac ${ }^{\circledR}(\mathrm{M}$; Ca soap of palm fatty acid distillate, Volac Ltd, Royston, Hertfordshire, UK) or fish oil (F; Trouw UK Ltd, Northwich, Cheshire, UK) supplemented with either 50 (B) or 500 (S) mg $\alpha$-tocopherol $/ \mathrm{kg}$ acetate. For details of diets and procedures, see Table 1 and p. 550. Values are means with standard errors shown by vertical bars (three lambs per group). as was an interaction between maternal vitamin $\mathrm{E}$ supplementation level and fatty acid source with the vitamin E concentration of plasma increasing in the order $\mathrm{FB}<\mathrm{MB}<\mathrm{FS}<\mathrm{MS}$. Plasma concentrations were similar for ewes and lambs at $14 \mathrm{~d}$ postpartum, with a positive correlation between ewe and lamb vitamin E status $(r$ 0.50, $P<0 \cdot 01)$. Vitamin $\mathrm{E}$ supplementation of the ewe had no effect upon the activity of GPx in erythrocytes of the 14-d-old lamb (Table 3). By contrast, lambs suckling ewes fed long-chain PUFA had lower GPx activity than those from the Megalac treatments $(P<0 \cdot 05)$. Maternal fish oil supplementation also increased serum CK concentrations in lambs at $14 \mathrm{~d}$ of age $(P<0.05)$, whilst there was no significant effect of maternal vitamin $\mathrm{E}$ supplementation upon this parameter.

\section{Discussion}

The aim of the present study was to determine the effects of vitamin $\mathrm{E}$ and long-chain PUFA supplementation of the pregnant and lactating ewe upon the vitamin $\mathrm{E}$ status of the neonatal and growing lamb. Work published by Mino \& Nishino (1973), Njeru et al. (1994) and Léger et al. (1998) concentrated on the relationship between maternal and neonatal plasma concentrations as the principal indicator of vitamin $\mathrm{E}$ status and concluded that low plasma concentrations in the neonate are indicative of negligible placental transfer. However, there are few data available regarding the

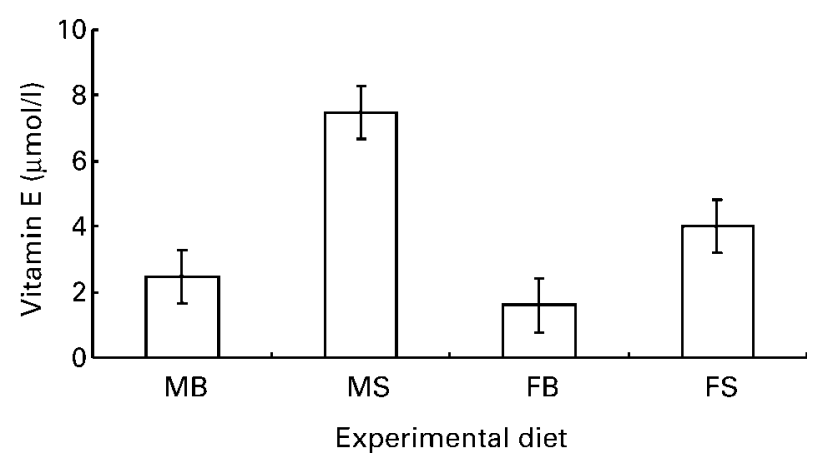

Fig. 3. Plasma vitamin $E$ concentrations in suckling lambs at $14 \mathrm{~d}$ of age from ewes fed diets containing Megalac ${ }^{\circledR}(\mathrm{M}$; Ca soap of palm fatty acid distillate, Volac Ltd, Royston, Hertfordshire, UK) or fish oil (F; Trouw UK Ltd, Northwich, Cheshire, UK) supplemented with either 50 (B) or 500 (S) mg $\alpha$-tocopherol acetate $/ \mathrm{kg}$. For details of diets and procedures, see Table 1 and p. 550. Values are means with standard errors shown by vertical bars (twenty-four lambs per group). 
vitamin E concentration of neonatal ruminant tissues, specifically brain tissue.

\section{Ewe antioxidant status}

A rapid increase in the plasma vitamin E concentration has been demonstrated as a response to dietary supplementation of ewes (Hidiroglou et al. 1969; Njeru et al. 1994) and pigs (Mahan, 1991; Hidiroglou et al. 1993a; Lauridsen et al. 2002). Within the present study, supranutritional supplementation of the pregnant and lactating ewe resulted in an increase in plasma vitamin E concentrations, results that concur with the range reported by Gabryszuk \& Klewiec (2002). The magnitude of changes in plasma vitamin $\mathrm{E}$ concentration in response to dietary supply was demonstrably higher during pregnancy than during lactation. Similar results were reported by Hidiroglou et al. (1993a), who supplemented pregnant and lactating sows with dietary vitamin $\mathrm{E}$ and attributed the lower plasma vitamin $\mathrm{E}$ concentrations observed during lactation to the partitioning of vitamin $\mathrm{E}$ into colostrum and milk. The total dietary vitamin E supply ( $\mathrm{mg} / \mathrm{d})$ was considerably higher during lactation than that fed during pregnancy, and it is probable that the lower concentrations observed in plasma may also have been due to the increased vitamin E requirement during lactation. The animal's requirement for vitamin $\mathrm{E}$ in its role as a cellular antioxidant is positively correlated with the oxidative challenge posed to the animal as a result of fatty acid supply. Farnworth et al. (1995) and McGuire \& Fritsche (1997) have described the abrogating effect of supplemental dietary long-chain PUFA upon the vitamin E status of various animals. The reduced plasma vitamin $\mathrm{E}$ concentrations observed in ewes fed fish oil during pregnancy and lactation concur with these results.

High concentrations of vitamin $\mathrm{E}$ in colostrum as a result of supplementation of the pregnant ewe have been reported by Gentry et al. (1992) and Njeru et al. (1994). The colostrum vitamin $\mathrm{E}$ concentrations reported herein mirror the values recorded in ewe plasma at $14 \mathrm{~d}$ prepartum, with significantly higher concentrations observed as a result of supranutritional supplementation. The increase in milk vitamin E concentrations conferred by supranutritional supplementation within the present study concurs with the results published by Mahan (1991), Charmley et al. (1993) and Njeru et al. (1994). Furthermore, the lower concentrations of vitamin $\mathrm{E}$ in milk compared with colostrum are in agreement with the results of Hidiroglou et al. (1993a) and Njeru et al. (1994) who observed a threefold increase in colostrum vitamin E compared with that of milk. Mahan (1991) described a similar pattern of vitamin $\mathrm{E}$ secretion in lactating sows given supplemental dietary vitamin $\mathrm{E}$ and proposed that increased concentrations in colostrum compared with milk may be a result of mobilisation of the labile tissue pool for colostrum production, with a consequent reliance on dietary vitamin $\mathrm{E}$ for deposition in milk.

The vitamin E status of the ewe has a complex relationship with the Se status of the animal, specifically with the GPx enzymes, which act to prevent the oxidation of unsaturated fatty acids within the cell (Van Metre \& Callan, 2001). Suárez et al. (1999) reported that supplementing rats with dietary vitamin E reduced the total amount of GPx present in liver and brain and suggested that this reduction may be due to a sparing effect of vitamin $\mathrm{E}$ upon the synthesis of GPx. By contrast, within the present study, no effect of vitamin E supplementation was observed upon the activity of GPx in ewes, although this activity was significantly reduced in ewes offered fish oil. The reduction in GPx activity in ewes supplemented with fish oil may be attributed to a higher rate of GPx utilisation within the cell and a reduction in active enzyme availability. Indeed, reduced GPx activity in erythrocytes of sheep supplemented with protected PUFA was reported by Smith et al. (1994).

Cellular contents are released when tissues are damaged by long-chain PUFA peroxidation (Lefebvre et al. 1996), with the serum enzyme CK acting as a reliable indicator of tissue damage (Sacheck \& Blumberg, 2001). However, neither PUFA nor vitamin $\mathrm{E}$ supplementation had a significant effect upon ewe serum CK within the present study, despite the potential differences in peroxidation challenge and antioxidant supply provided by the four treatment diets. Reference values for CK in sheep serum proposed by Bostedt \& Schramel (1990) suggest that the extent of tissue damage induced by long-chain PUFA supplementation within the present study was low, with values of greater than 2000 IU/l suggesting sub-clinical, and above $4000 \mathrm{IU} / 1$ acute nutritional myopathy.

\section{Lamb birth weight}

Increasing birth weight may improve neonatal survival with an improvement in piglet survival rate as a result of vitamin E supplementation of the sow being reported by Mahan (1991). Reduced pre-weaning mortality rates in lambs produced by ewes supplemented with vitamin E were also reported by Kott et al. (1983, 1998) and Gabryszuk \& Klewiec (2002). The increase in lamb birth weight conferred by maternal vitamin $\mathrm{E}$ supplementation in the present study concurs with previous research published by Gentry et al. (1992), who reported that lambs from vitamin E-supplemented ewes tended to have higher birth weights and increased pre-weaning live weight gains. The mechanism by which birth weight may be increased by vitamin E supplementation is unclear; however, it may, in part, be due to the effects of antioxidant vitamins upon the immune system. Supplementary vitamin E has been reported to augment immune status and reduce the incidence and symptoms of disease in ruminant animals (Reddy et al. 1986). Consequently, improving the maternal immune status during pregnancy may promote the partitioning of additional nutrients towards the growing fetus, thereby increasing growth in utero. Long-chain PUFA supplementation of the dam has been shown to increase birth weight in human and animal neonates (Crawford et al. 1997; Rooke et al. 2001). In the present study, lamb birth weights were numerically higher as a result of fish oil supplementation of the ewe, although these results did not reach statistical significance.

\section{Neonatal lamb antioxidant status}

Concentrations of vitamin E within neonatal lamb plasma were low and unaffected by treatment diet. This result is in agreement with those reported by other authors in neonatal human subjects (Mino \& Nishino, 1973; Léger et al. 1998), rats (Martin \& Hurley, 1977), domestic pigs (Hidiroglou et al. 1993a, 1995), cattle (Van Saun et al. 1989) and sheep (Hidiroglou et al. 1969; Njeru et al. 1994) with the consensus view being that it is indicative of low placental transfer, therefore rendering the neonate deficient in vitamin E. Furthermore, Lauridsen et al. (2002) concluded that low tissue concentrations of vitamin $\mathrm{E}$ in neonatal piglets were evidence 
of inefficient placental transfer and suggested that neonatal vitamin E status could not be manipulated by maternal supplementation.

The present data do not support the hypothesis that placental transfer is negligible in the ruminant. Although neonatal plasma vitamin $\mathrm{E}$ concentrations were low or undetectable for all treatments, brain and semimembranosis concentrations were significantly increased by supranutritional maternal supplementation. Kelly et al. (1992) suggested that the fetal liver may act as a labile source of vitamin $\mathrm{E}$ and that plasma concentrations may not be a reliable indicator of neonatal vitamin $\mathrm{E}$ status. It is debatable whether low vitamin $\mathrm{E}$ concentrations in neonatal plasma indicate a deficiency status or an increased rate of uptake from plasma in order to maintain satisfactory tissue concentrations. Furthermore, Vatassery et al. (1988) hypothesised that the rodent brain may be resistant to vitamin $\mathrm{E}$ depletion even when a vitamin E-deficient diet is supplied for a period of 4 months. It therefore seems logical that organs with an increased requirement for antioxidant vitamins may have an enhanced capacity for uptake in times of diminished availability.

Within the present study, vitamin E concentrations in neonatal tissues were considerably higher than those observed by Hidiroglou et al. (1993b), suggesting that increasing the maternal vitamin E supply may enhance the amount of this vitamin transferred across the placenta to the fetal lamb. Supranutritional vitamin E supplementation of ewes resulted in concentrations of vitamin $\mathrm{E}$ in neonatal lamb muscle similar to those reported for unsupplemented wethers by Ochoa et al. (1992). However, Hidiroglou \& Batra (1996) observed a mean value of $2.70 \mu \mathrm{g} / \mathrm{g}$ in muscle of lambs with no supplemental vitamin $\mathrm{E}$ added to the diet. It would appear that although supplementation increased the concentration of vitamin $\mathrm{E}$ in neonatal tissues within the present study, these animals may still have been sub-clinically deficient in vitamin $\mathrm{E}$. The reduction in tissue vitamin $\mathrm{E}$ concentration in lambs born to ewes fed diets supplemented with longchain PUFA concurs with the results of Hidiroglou et al. (1970) and Farnworth et al. (1995), again suggesting that these diets conferred a greater peroxidation challenge.

\section{Suckling lamb antioxidant status}

Concentrations of vitamin $\mathrm{E}$ within ewe and lamb plasma were similar at $14 \mathrm{~d}$ into lactation, the increases in plasma vitamin $\mathrm{E}$ concentration of suckling lambs conferred by maternal supranutritional supplementation reflecting differences observed in maternal milk. Dosing lambs with $1000 \mathrm{IU} \mathrm{D}-\alpha$-tocopherol increased plasma vitamin E concentrations from 0.65 to $1.90 \mu \mathrm{g} / \mathrm{ml}$ in the study of Hidiroglou \& Batra (1996), values consistent with the lowest concentrations observed in lambs within the present study. The plasma concentrations observed here were also within the range reported by Gentry et al. (1992) and Hatfield et al. (2002). The lower vitamin E concentrations observed in lambs suckling ewes supplemented with long-chain PUFA are in agreement with the results found by McGuire \& Fritsche (1997) in rats fed additional dietary fish oil and with those of Chikunya et al. (2004) and Demirel et al. (2004) in sheep.

Activity of GPx within erythrocytes was approximately doubled in lambs at $14 \mathrm{~d}$ of age compared with ewe erythrocyte activities. Although placental transfer of Se appears to be limited in the ewe (Bostedt \& Schramel, 1990) no barrier to mammary Se transfer is apparent, which may enhance synthesis and activity of GPx in suckling lambs. The activity of this enzyme in lamb erythrocytes was reduced by maternal long-chain PUFA supplementation, concurring with patterns observed in maternal plasma during lactation. This may be attributed to an increase in cellular oxidative challenge resulting from the addition of PUFA to the maternal diet with consequent transfer of these fatty acids into milk.

Serum CK concentrations observed in lambs at $14 \mathrm{~d}$ of age concur with maternal CK results, in that the concentrations of this enzyme were significantly augmented by long-chain PUFA supplementation of the ewe. El-Neweehy et al. (2000) reported low concentrations of $\mathrm{CK}$ in animals free of nutritional myopathy (37 IU/l), although sub-clinically affected animals had concentrations ranging from 1186 to $3740 \mathrm{IU} / 1$ with detectable symptoms being seen at a mean CK concentration of $4291 \mathrm{IU} / \mathrm{l}$. By these criteria, although lambs suckling ewes fed fish oil had an increased susceptibility to nutritional myopathy, clinical disease was unlikely to be present.

\section{Conclusion}

Previous studies have suggested that the placental transfer of vita$\min \mathrm{E}$ from the ewe to the lamb is negligible. However, the present experiment demonstrates that appreciable placental transfer and subsequent deposition of vitamin $\mathrm{E}$ into neonatal lamb tissues may be conferred by vitamin $\mathrm{E}$ supplementation of the pregnant ewe. Furthermore, it can be concluded that plasma vitamin E concentrations are not reliable indicators of tissue concentrations in the neonate. The exact mechanism by which vitamin E supplementation increases lamb birth weight warrants further investigation.

\section{Acknowledgements}

The authors wish to thank the Oldacre Foundation for financial assistance, Trouw Nutrition UK for the provision of feedstuffs, and Roche UK Ltd for the provision of vitamin supplements and vitamin analysis within feed.

\section{References}

Agricultural and Food Research Council (1993) Energy and Protein Requirements of Ruminants. An advisory manual prepared by the AFRC Technical Committee on Responses to Nutrients. Oxford: CAB International.

Association of Official Analytical Chemists (1990) Official Methods of Analysis, 15th ed. Arlington, VA: AOAC.

Bostedt H \& Schramel P (1990) The importance of selenium in the prenatal and postnatal development of calves and lambs. Biol Trace Elem Res 24, 163-171.

Burton GW, Webb A \& Ingold KU (1985) A mild, rapid and efficient method of lipid extraction for use in determining vitamin E/lipid ratios. Lipids 20, 29-39.

Capper JL, Wilkinson RG, Sinclair LA, Pattinson SE \& Mackenzie AM (2002) The effect of long-chain polyunsaturated fatty acid and vitamin E supplementation of ewes on neonatal lamb vigour, lamb growth and colostrum parameters. Proceedings of the British Society of Animal Science Annual Meeting 2002, p. 7. Edinburgh: British Society of Animal Science.

Carlson SE \& Werkman SH (1996) A randomized trial of visual attention of preterm infants fed docosahexaenoic acid until two months. Lipids 31, 85-90.

Charmley E, Nicholson JWG \& Zee JA (1993) Effect of supplemental vitamin $\mathrm{E}$ and selenium in the diet on vitamin $\mathrm{E}$ and selenium levels and control of oxidized flavor in milk from Holstein cows. Can $J$ Anim Sci 73, 453-457. 
Chikunya S, Demirel G, Enser M, Wood JD, Wilkinson RG \& Sinclair LA (2004) Biohydrogenation of dietary $n-3$ PUFA and stability of ingested vitamin $E$ in the rumen, and their effects on microbial activity in sheep. Br J Nutr 91, 539-550.

Cooper SL, Sinclair LA, Wilkinson RG, Chikunya S, Hallett K, Enser M \& Wood JD (2002) Rumen biohydrogenation of polyunsaturated fatty acid sources and their effect on plasma fatty acid status in sheep. Proceedings of the British Society of Animal Science Annual Meeting 2002, p. 177. Edinburgh: British Society of Animal Science.

Cooper SL, Sinclair LA, Wilkinson RG, Hallett KG, Enser M \& Wood JD (2004) Manipulation of the $n-3$ polyunsaturated fatty acid content of muscle and adipose tissue in lambs. J Anim Sci 82, 1461-1470.

Crawford MA, Costeloe K, Ghebremeskel K, Phylactos A, Skirvin L \& Stacey F (1997) Are deficits of arachidonic and docosahexaenoic acids responsible for the neural and vascular complications of preterm babies? Am J Clin Nutr 66, Suppl., 1032S-1041S.

Demirel G, Wachira AM, Sinclair LA, Wilkinson RG, Wood JD \& Enser M (2004) Effects of dietary $n-3$ polyunsaturated fatty acids, breed and dietary vitamin $\mathrm{E}$ on the fatty acids of lamb muscle, liver and adipose tissue. Br J Nutr 91, 551-565.

El-Neweehy TK, Al-Qarawi AA \& Abel-Rahman HA (2000) Some studies on stiff lamb disease in Qassim region in Saudi Arabia. 1: Enzymatic profile in free, subclinically and clinically affected lambs both before and after treatment with vitamin $\mathrm{E}$ and selenium preparation. Small Rumin Res 35, 219-223.

Farnworth ER, Butler G \& Hidiroglou M (1995) Fetal pig vitamin E status. Nutr Res 15, 1139-1147.

Gabryszuk M \& Klewiec J (2002) Effect of injecting 2- and 3-year-old ewes with selenium and selenium-vitamin $\mathrm{E}$ on reproduction and rearing of lambs. Small Rumin Res 43, 127-132.

Gentry PC, Ross TT, Oetting BC \& Birch KD (1992) Effects of supplemental $\mathrm{D}-\alpha$-tocopherol on preweaning lamb performance, serum and colostrum tocopherol levels and immunoglobulin $\mathrm{G}$ titers. Sheep Res $J$ 8, 95-100.

Givens DI, Cottrill BR, Davies M, Lee PA, Mansbridge RJ \& Moss AR (2000) Sources of $n-3$ polyunsaturated fatty acids additional to fish oil for livestock diets - a review. Nutr Abstr Rev (Ser B) 70, 1-19.

Hatfield PG, Robinson BL, Minikhiem DL, et al. (2002) Serum $\alpha$-tocopherol and immune function in yearling ewes supplemented with zinc and vitamin E. J Anim Sci 80, 1329-1334.

Hidiroglou M \& Batra TR (1996) Plasma and tissue concentrations of vitamin $\mathrm{E}$ following supplementation of two forms of vitamin $\mathrm{E}$ in sheep. Small Rumin Res 21, 83-87.

Hidiroglou M, Hoffman I \& Jenkins KJ (1969) Selenium distribution and radiotocopherol metabolism in the pregnant ewe and fetal lamb. Can $J$ Physiol Pharmacol 47, 953-962.

Hidiroglou M, Jenkins KJ, Lessard JR \& Borowsky E (1970) Effect of feeding cod liver oil on the fate of radiotocopherol in sheep. Can J Physiol Pharmacol 48, 751-757.

Hidiroglou M, Farnworth E \& Butler G (1993a) Effects of vitamin E and fat supplementation on concentration of vitamin $E$ in plasma and milk of sows and in plasma of piglets. Int J Vitam Nutr Res 63, 180-187.

Hidiroglou M, Farnworth E \& Butler G (1993b) Vitamin E and fat supplementation of sows and the effect on tissue vitamin E concentrations in their progeny. Reprod Nutr Dev 33, 557-565.

Hidiroglou M, Batra TR, Farnworth ER \& Markham F (1995) Effect of vitamin $\mathrm{E}$ supplementation on immune status and $\alpha$-tocopherol in plasma of piglets. Reprod Nutr Dev 35, 443-450.

Hidiroglou N, Madere R \& McDowell L (2001) Maternal transfer of vitamin $\mathrm{E}$ to fetal and neonatal guinea pigs using a stable isotopic technique. Nutr Res 21, 771-783.

Innis SM (1991) Essential fatty acids in growth and development. Prog Lipid Res 30, 3-103.

Kelly FJ, Safavp M \& Cheeseman KH (1992) Tissue $\alpha$-tocopherol status during late fetal and early neonatal life of the guinea-pig. Br J Nutr 67, $457-462$.
Kott RW, Ruttle JI \& Southward GM (1983) Effects of vitamin E and selenium injections on reproduction and preweaning lamb survival in ewes consuming diets marginally deficient in selenium. J Anim Sci 57, 553-558.

Kott RW, Thomas VM, Hatfield PG, Evans T \& Davis KC (1998) Effects of dietary vitamin E supplementation during late pregnancy on lamb mortality and ewe productivity. J Am Vet Med Assoc 212, 997- 1000 .

Lauridsen C, Engel H, Jensen SK, Craig AM \& Traber MG (2002) Lactating sows and suckling piglets preferentially incorporate $R R R$ - over allrac- $\alpha$-tocopherol into milk, plasma and tissues. $J$ Nutr 132, $1258-1264$.

Lefebvre HP, Laroute V, Braun JP, Lassourd V \& Toutain PL (1996) Noninvasive and quantitative evaluation of post-injection muscle damage by pharmacokinetic analysis of creatine kinase release. Vet Res 27, 343-361.

Léger CL, Dumontier C, Fouret G, Boulot P \& Descomps B (1998) A short term supplementation of pregnant women before delivery does not improve significantly the vitamin E status of neonates - low efficiency of the vitamin E placental transfer. Int J Vitam Nutr Res 68, 293-299.

Liu Q, Scheller KK \& Schaefer DM (1996) Technical note: a simplified method for vitamin E determination in beef muscle. J Anim Sci 74, 2406-2410.

McGuire SO \& Fritsche KL (1997) The effect of dietary menhaden fish oil on $\alpha$-tocopherol status in rodents is both concentration and tissue dependent. Nutr Biochem 8, 518-526.

McMurray CH \& Blanchflower WJ (1979) Application of a high-performance liquid chromatographic fluorescence method for the rapid determination of $\alpha$-tocopherol in the plasma of cattle and pigs and its comparison with direct fluorescence and high-performance liquid chromatography-ultraviolet detection methods. $J$ Chromatogr 178, 525-531.

Mahan DC (1991) Assessment of the influence of dietary vitamin E on sows and offspring in three parities: reproductive performance, tissue tocopherol and effects on progeny. J Anim Sci 69, 2904-2917.

Mahan DC \& Vallet JL (1997) Vitamin and mineral transfer during foetal development and the early postnatal period in pigs. J Anim Sci 75, $2731-2738$.

Malone JI (1975) Vitamin passage across the placenta. Clin Perinatol 2, 295-307.

Manz U \& Philipp K (1981) A method for the routine determination of $\alpha$ tocopherol in complete feeds, premixes and vitamin concentrates with the aid of high performance liquid chromatography. Int J Vitam Nutr Res 51, 342-348.

Martin MM \& Hurley LS (1977) Effect of large amounts of vitamin E during pregnancy and lactation. Am J Clin Nutr 30, 1629-1637.

Merrell BG (1998) The effects on lamb survival rate of supplementing ewes with vitamin E during late pregnancy. Sheep Vet Soc Proc 22, 57-61.

Mino M \& Nishino H (1973) Fetal and maternal relationship in serum vitamin E level. J Nutr Sci Vitaminol (Tokyo) 19, 475-482.

Njeru CA, McDowell LR, Wilkinson NS, Linda SB \& Williams SN (1994) Pre- and postpartum supplemental DL- $\alpha$-tocopheryl acetate effects on placental and mammary vitamin $\mathrm{E}$ transfer in sheep. J Anim Sci 72, 1636-1640.

Ochoa L, McDowell LR, Williams SN, Wilkinson N, Boucher J \& Lentz EL (1992) $\alpha$-Tocopherol concentrations in serum and tissues of sheep fed different sources of vitamin E. J Anim Sci 70, 2568-2573.

O'Connor CE \& Lawrence AB (1992) Relationship between lamb vigour and ewe behaviour at parturition. Anim Prod 54, 361-366.

Pattinson SE \& Thomas EW (2004) The effect of sire breed on colostrum production of crossbred ewes. Livestock Prod Sci 86, 47-53.

Reddy PG, Morrill JL, Minocha HC, Morrill MB, Dayton AD \& Frey RA (1986) Effects of supplemental vitamin $\mathrm{E}$ on the immune system of calves. J Dairy Sci 69, 164-171.

Rooke JA, Sinclair AG \& Edwards SA (2001) Feeding tuna oil to the sow at different times during pregnancy has different effects on piglets' 
long-chain polyunsaturated fatty acid composition at birth and subsequent growth. Br J Nutr 86, 21-30.

Russel AJF, Doney JM \& Gunn RG (1969) Subjective assessment of body fat in live sheep. J Agric Sci 72, 451-454.

Sacheck JM \& Blumberg JB (2001) Role of vitamin E and oxidative stress in exercise. Nutrition 17, 809-814.

Slee J (1981) A review of genetic aspects of survival and resistance to cold in newborn lambs. Livestock Prod Sci 8, 419-429.

Smith GM, Fry JM, Allen JG \& Costa ND (1994) Plasma indicators of muscle damage in a model of nutritional myopathy in weaner sheep. Aust Vet J 71, 12-17.

Suárez A, Ramírez-Tortosa M, Gil A \& Faus M-J (1999) Addition of vitamin $\mathrm{E}$ to long-chain polyunsaturated fatty acid-enriched diets protects neonatal tissue lipids against peroxidation in rats. Eur $J$ Nutr 38, 169-176

US Department of Agriculture Plant and Animal Health Inspection Service (2001) Guidelines for investigating suspect West Nile virus cases in equine: procedure for collecting brain tissue. http://www. aphis.usda.gov/lpa/issues/wnv/wnvguide.html

Van Metre DC \& Callan RJ (2001) Selenium and vitamin E. Vet Clin North Am Food Anim Pract 17, 373-402.
Van Saun RJ, Herdt TH \& Stowe HD (1989) Maternal and fetal vitamin E concentrations and selenium-vitamin E interrelationships in dairy cattle. J Nutr 119, 1156-1164.

Van Soest PJ, Robertson JB \& Lewis BA (1991) Methods for dietary fibre, neutral detergent fiber, and nonstarch polysaccharides in relation to animal nutrition. $J$ Dairy Sci 74, 3583-3597.

Vatassery GT, Brin MF, Fahn S, Kayden HJ \& Traber MG (1988) Effect of high doses of dietary vitamin $\mathrm{E}$ on the concentrations of the vitamin $\mathrm{E}$ in several brain regions, plasma, liver and adipose tissue of rats. $J$ Neurochem 51, 621-623.

Wachira AM, Sinclair LA, Wilkinson RG, Hallett K, Enser M \& Wood JD (2000) Rumen biohydrogenation of $n-3$ polyunsaturated fatty acids and their effects on microbial efficiency and nutrient digestibility in sheep. J Agric Sci 135, 419-428.

Wachira AM, Sinclair LA, Wilkinson RG, Enser M, Wood JD \& Fisher AV (2002) Effects of dietary fat source and breed on the carcass composition, $n-3$ polyunsaturated fatty acid and conjugated linoleic acid content of sheep meat and adipose tissue. Br J Nutr 88, $697-709$.

Wang X \& Quinn PJ (1999) Vitamin E and its function in membranes. Prog Lipid Res 38, 309-336. 